\title{
Atemoya sap flow estimation as a function of leaf area and reference evapotranspiration
}

\author{
Irai Manuela Santana Santos ${ }^{1}$, Lucas Melo Vellame ${ }^{2}$, Lígia Borges Marinho ${ }^{3}$, Jairton Fraga Araújo ${ }^{4}$
}

\begin{abstract}
The aim of this study was to quantify the water consumption of two atemoya cultivars in irrigated orchards using the thermal dissipation probe (TDP) method, relating transpiration with leaf area and evaporative demand of the atmosphere. The experiment was carried out in two atemoya orchards with young and adult plants of 'Gefner' and 'African Pride' cultivars at the experimental field of the University of the State of Bahia, in Juazeiro-BA. Plants sap flow was determined by TDP and vegetative growth, and meteorological variables were obtained. The sap flow of young atemoya plants reached maximum values of 10.2 and $8.4 \mathrm{~L} \mathrm{plant}^{-1}$ day $^{-1}$, in 'Gefner' and 'African Pride' cultivars, respectively. In adult plants, these values were $50.1 \mathrm{~L} \mathrm{plant}^{-1}$ day $^{-1}$ in 'Gefner' cultivar and 98.2 $\mathrm{L} \mathrm{plant}^{-1}$ day $^{-1}$ in 'African Pride' cultivar. The relationship between sap flow and leaf area showed linearity only for a given leaf area range, in both cultivars and orchards. Sap flow estimated from the product between leaf area and reference evapotranspiration can be used provided that the leaf area limits in which this relationship occurs, in each variety, are considered.
\end{abstract}

Index terms: anonaceous, transpiration, leaf area, atmospheric demand

\section{Estimativa do fluxo de seiva da atemoeira em função da área foliar e evapotranspiração de referência}

Corresponding author: irai.manuela@gmail.com

Received: May 31, 2021 Accepted: August 16, 2021

Copyright: All the contents of this journal, except where otherwise noted, is licensed under a Creative Commons Attribution License.
Resumo - Objetivou-se quantificar o consumo hídrico de duas cultivares de atemoia, em pomares irrigados, pelo método da sonda de dissipação térmica (SDT), relacionando a transpiração com a área foliar e a demanda evaporativa da atmosfera. $\mathrm{O}$ experimento foi realizado em dois pomares de atemoia com plantas jovens e adultas, das cultivares Gefner e African Pride, no campo experimental da Universidade do Estado da Bahia, em Juazeiro-BA. Determinou-se o fluxo de seiva das plantas por meio de SDT e do crescimento vegetativo; bem como foram obtidas as variáveis meteorológicas. O fluxo de seiva nas plantas de atemoia, no pomar jovem, atingiu valores máximos de 10,2 e 8,4 L planta $^{-1} \mathrm{dia}^{-1}$, nas cultivares Gefner e African Pride, respectivamente. Nas plantas do pomar adulto, esses valores foram de 50,1 L planta ${ }^{-1}, \mathrm{dia}^{-1}$ na Gefner, e de 98,2 L planta ${ }^{-1} \mathrm{dia}^{-1}$, na African Pride. A relação entre o fluxo de seiva e a área foliar apresentou linearidade apenas para determinada faixa de área foliar, em ambas as cultivares e pomares. A estimativa do fluxo de seiva, a partir do produto da área foliar e da evapotranspiração de referência, pode ser utilizada desde que sejam considerados os limites de área foliar em que essa relação ocorre, em cada variedade.

Termos para indexação: anonáceas, transpiração, área foliar, demanda atmosférica. 


\section{Introduction}

Atemoya, a hybrid of the annonaceae family, has some of the good characteristics of cherimoya associated with others of sugar apple. Due to variations present in the parental species, there are atemoya cultivars with different characteristics, with the possibility of adaptation to different climatic conditions. 'Gefner' cultivar, of Israeli origin, stands out as one of the most promising cultivars available today, as it meets most requirements demanded in the productive and commercial sphere, such as productivity and vigor, size and well-defined appearance of fruits with pulp flavor and aroma (MOSCA et al., 2006). In the semiarid region of northeastern Brazil, this variety has been preferred, apparently because it adapts better to conditions of higher temperatures (LEMOS, 2014). In addition, the 'African Pride' cultivar, originating in Australia, stands out, being the most similar to cherimoya.

Atemoya trees are semideciduous plants and enter a dormant period, losing their leaves in periods of drought or low temperatures (BRICKELL; JOYCE, 2017; SILVA et al., 2006). In the summer, high temperatures induce rapid vegetative growth, along with the appearance of flowers. The use of complementary management techniques, such as pruning, defoliation and pollination, is essential for the crop success, minimizing the problem of crop concentration only in a single period of the year (HAWERROTH et al., 2014), which is an important tool to regulate the market and provide better prices to producers. Thus, the pruning of atemoya is among crop treatments suitable for its good development and production. The differentiated crop management, with the occurrence of plant defoliation for production, impairs the use of traditional methods to determine its water consumption and thus an efficient irrigation management. Mata-González et al., (2005) reported that the use of crop coefficients does not adequately estimate crop evapotranspiration in arid environments, as the method was developed assuming that plants have high leaf area index and low transpiration resistance.

As an alternative to overcome the difficulty of water management in orchards, some authors have carried out studies aimed at modeling transpiration, in which the leaf area is used as variable for standardizing transpiration, and, subsequently, being related to atmospheric demand (ETo), which can reduce variation resulting from tree size and planting spacing (COELHO FILHO et al., 2004; OLIVEIRA et al., 2009). Witght et al. (1986) used a model that considered the leaf area index to calculate the potential transpiration of native semiarid pasture as a function of ETo and crop coefficient. According to Pereira et al. (2009), the use of transpiration modeling presents simple calculation; however, its application is specific to each species and meteorological conditions under study.
As a methodology for observing plant transpiration, sap flow measurements are characterized as an alternative capable of providing water use estimates in whole trees and at different spatiotemporal scales (PAÇO et al., 2014; PETERS et al. 2018). The thermal dissipation probe method, developed by Granier (1985) for determining sap flow relates the heat dissipation rate to the sap flow, being simpler in terms of instrumentation, in addition to being of easy manufacture and probe installation (HÖLTTÄ et al., 2015), when compared with other methods. Santos et al. (2020) concluded that sap flow estimation by the Granier method, with correction of natural thermal differences and modification of the angular coefficient of the equation, was satisfactory to estimate atemoya transpiration, with mean absolute error of $3.1 \%$. The authors, however, observed sap flow overestimation in relation to lysimetric measurements that may be related to the water redistribution in the plant as a function of the occurrence of nocturnal sap flow and also indicate temporal differences between sap flow and transpiration processes.

Based on the above, this work aims to quantify the water consumption by atemoya crop by the thermal dissipation probe method, as well as its relationship with leaf area and evaporative demand of the atmosphere, in order to provide a basis for the planning and water management in the crop.

\section{Material and methods}

The experiment was carried out in the municipality of Juazeiro-BA (latitude $09^{\circ} 24^{\prime} 50^{\prime \prime} \mathrm{S}$; longitude $40^{\circ}$ 30' 10" W; altitude $368 \mathrm{~m}$ a.s.1.), in the Sub middle São Francisco Valley region, from December 2017 to May 2019. According to Koppen's classification, the climate is of warm semi-arid type (BSwh), with average annual rainfall of $540 \mathrm{~mm}$.

In order to carry out this study, experiments were carried out at the same time in two atemoya orchards, using 'Gefner' and 'African Pride' varieties from seedlings grafted onto sugar apple (Annona squamosa). Plants were grown in open field under different growing conditions and age in soil classified as Fluvic Neosol. For evaluation, four plants of each variety were selected in each orchard.

In the first study, the experiment was conducted from December 2017 to May 2019 using adult plants with approximately fifteen years of age implanted in a randomized block design with spacing of $6 \times 5 \mathrm{~m}$. The orchard was set up in an area of $1680 \mathrm{~m}^{2}$ and for some years, the crop was conducted under organic production system, later changing to the conventional cultivation system. The irrigation system adopted in the area was a micro-sprinkler irrigation system with flow rate of $50 \mathrm{~L}$ hour $^{-1}$. 
The second study was carried out between April 2018 and April 2019 in three-year-old plants implanted in a randomized block design with spacing of $4 \times 4 \mathrm{~m}$, intercropped with castor bean and pineapple in organic cultivation system. The orchard has area of approximately $960 \mathrm{~m}^{2}$, irrigated by micro-sprinkler irrigation system with flow rate of $340 \mathrm{~L} \mathrm{hour}^{-1}$.

Experiments were carried out relating sap flow determined by the thermal dissipation probe method with leaf area and evaporative demand of the atmosphere. Sap flow was calculated using the Granier equation calibrated for atemoya by Santos et al (2020) (Eq. 1).

$$
\mathrm{SF}=0,000103\left(\frac{\Delta \mathrm{Tm}-\Delta \mathrm{T}}{\Delta \mathrm{T}}\right)^{1,231} \cdot \mathrm{AS}(\mathrm{R} 2=0.93)
$$

Where: $\mathrm{SF}=$ sap flow $\left(\mathrm{m}^{3} \mathrm{~s}^{-1}\right) ; \Delta \mathrm{Tm}=$ temperature difference between the two probes in the zero flow situation $\left({ }^{\circ} \mathrm{C}\right) ; \Delta \mathrm{T}=$ current temperature difference $\left({ }^{\circ} \mathrm{C}\right)$; and $\mathrm{AS}=$ area of the xylem sap conduction section $\left(\mathrm{m}^{2}\right)$.

Thermal dissipation probes were constructed with $2.0 \mathrm{~cm}$ in length using copper-constantan thermocouples of $0.5 \mathrm{~mm}$ in diameter inserted into hypodermic needles of $1.0 \mathrm{~mm}$ in internal diameter, filled with resin for fixation. A heating element formed by a constantan thread was mounted on the upper probe around the needle, allowing heating, by the Joule effect, with continuous dissipation.

To install probes in the plant stem, two holes were made in the same axial line of the stem spaced $7.0 \mathrm{~cm}$. After installing probes, the stem segment was coated with aluminum foil, and at the sensor site, a skirt-shaped shield was made using the same material as the stem coating, thus minimizing the effect of natural thermal gradients (VELLAME et al., 2011).

As a way to compensate for the effect of natural thermal differences (NTD), probes had the heating turned off every 15 days for a period of 24 hours according to methodology used by Vellame et al. (2009). Thus, the thermal differences were measured with the sensor not heated in periods different from the sap flow measurement and then, estimation models were generated through linear regression as a function of air temperature, individually for each probe.

To promote the heating of the upper probe, voltage was regulated according to the electrical resistance of the heating element of each sensor, with dissipated electrical power being kept close to $0.2 \mathrm{~W}$ as recommended in literature for the method, using adjustable voltage source. After being installed, sensors were connected to a data acquisition system (CR1000 and CR800 Series associated with channel multiplexer, Campbell Sci. In., Logan, UT). Information was generated every 30 seconds, with averages recorded every hour.
Throughout experiments, measurements of the plant stem diameter $(\mathrm{D}-\mathrm{cm})$ were periodically performed, from which it was possible to estimate the area of the xylem conduction section ( $\mathrm{AS}-\mathrm{cm}^{2}$ ), discounting the region occupied by the bark and the medulla area through Eq 2 (SANTOS, et al, 2020):

$$
\text { AS }=0.7844 \mathrm{D}^{2}-0.0046 \mathrm{D}-0.0117(\mathrm{R} 2=0.999)
$$

Leaf area was estimated through the product of the average leaf area value by the number of leaves of each atemoya plant evaluated. The total number of leaves was recorded and the length $(\mathrm{L}-\mathrm{cm})$ and width $(\mathrm{W}-\mathrm{cm})$ of $25 \%$ of the total leaves were measured. The area of each leaf $\left(\mathrm{LA}-\mathrm{cm}^{2}\right)$ was determined by Eq. 3 for the 'Gefner' variety and by Eq. 4 for the 'African Pride' variety.

$$
\begin{aligned}
& \mathrm{LA}=0.7039 \mathrm{~L} \mathrm{~W}\left(\mathrm{R}^{2}=0.999\right) \\
& \mathrm{LA}=0.7305 \mathrm{~L} \mathrm{~W}\left(\mathrm{R}^{2}=0.995\right)
\end{aligned}
$$

For days when it was not possible to determine the leaf area of plants, corresponding to intervals between measurements, the leaf area was obtained through linear interpolation between the leaf area value obtained in the measurement before and after data collection.

Pruning of atemoya plants was carried out during a large part of the crop cycle, as it is among the most suitable crop treatments for its good development and production, with fruiting pruning and green pruning being carried out on all plants under study.

In soil water monitoring for irrigation management, puncture tensiometers were used, being representatively installed in the plots of each variety. Soil water tension was measured using two tensiometer batteries in each plot, installed at depth of $1 / 4$ and $3 / 4$ of the effective root system depth $(50 \mathrm{~cm})$ and at distance of $60 \mathrm{~cm}$ from the trunk of atemoya plants. Irrigations were carried out by applying water to the soil up to the field capacity value determined by means of the soil water retention curve, adjusted by the van Genuchten model (1980) using data from the physical-water analysis for each study area.

Micrometeorological data were obtained from an automatic meteorological station located about $580 \mathrm{~m}$ from the experimental area with young plants and $90 \mathrm{~m}$ from the experimental area with adult plants. The reference evapotranspiration was calculated using the PenmanMonteith method, parameterized by FAO (ALLEN et al., 1998). 


\section{Results and discussion}

According to the analysis of variance (Table 1), sap flow was significantly different for atemoya cultivars in both young and adult orchards. The leaf area; however, only showed significant difference for the young orchard ( $F$ Test, $\mathrm{p}<0.05$ ). The average sap flow throughout the experimental period was higher for the 'Gefner' cultivar in the young orchard. The higher leaf area value of 'Gefner' plants in relation to 'African Pride' plants in this orchard is one of the factors that may have contributed to the higher flow rate found. Considering plants of the adult orchard, greater sap flow was observed for 'African Pride' plants (Table 1).

Table 1. Average sap flow (SF) and leaf area (LA) values of two atemoya varieties in young and adult orchards throughout the evaluation period

\begin{tabular}{ccccc}
\hline & \multicolumn{2}{c}{ Young orchard } & \multicolumn{2}{c}{ Adult orchard } \\
\hline & Gefner & African P. & Gefner & African P. \\
\hline SF $\left(\right.$ L day $\left.{ }^{-1}\right)$ & 5.8 & 2.2 & 17.9 & 27.0 \\
LA $\left(\mathrm{m}^{2}\right)$ & 11.2 & 7.2 & 22.4 & 23.0 \\
\hline
\end{tabular}

According to Pimentel (2004) and Coelho Filho et al (2011), the greater the photosynthetically effective leaf area, in which there is no limitation in the light energy interception, the greater the transpiration rate. However, internal factors such as number of stomata per $\mathrm{cm}^{2}$, leaf thickness, water potential and leaf morphology also directly influenced the transpiration process (KLARISYA \& DANINGSIH, 2021), affecting its interaction with other environmental factors (SIMÕES et al., 2019, COELHO FILHO et al., 2004).

Taiz et al. (2017) reported that transpiration depends on the difference in the water vapor concentration between leaf spaces and external air and on the resistance to diffusion of this route, whose control is regulated by stomata. Stomatal control is regulated both by environmental factors and by the anatomical and morphological aspects of leaves, varying depending on cultivar, which can influence the thickness of the border layer, changing the process dynamics. According to Coelho Filho et al. (2011), transpiration depends not only on the total leaf surface, but also on leaf density, which can cause self-shading, reducing transpiration.
Table 2 presents the multiple linear regression coefficients for estimating sap flow as a function of leaf area and reference evapotranspiration. Coefficients relating leaf area and evapotranspiration to sap flow were highly significant $(p<0.01)$. The significant relationship between SF with ETo and leaf area demonstrates the causal relationship between these variables and plant transpiration, which is directly related to variation in leaf stomatal conductance. However, the low correlation coefficients indicate that a simple linear model is not able to estimate transpiration as a function of these variables.

In Figure 1a, data of SF/ETo ratio and average leaf area of each variety between April 2018 and April 2019 in the young orchard are presented. From April to July 2018, the leaf area and the SF/ETo ratio showed little variation over time, with values between 0.86 and $2.4 \mathrm{~L} \mathrm{~mm}^{-1}$ for 'Gefner' plants and 0.19 and $0.70 \mathrm{~L} \mathrm{~mm}^{-1}$ for 'African Pride' plants. For this period, the mean sap flow was 6.33 $\mathrm{L}_{\text {plant }}{ }^{-1}$ day $^{-1}$ for 'Gefner' plants and 1.81 L plant ${ }^{-1}$ day $^{-1}$ for 'African Pride' plants.

Table 2. Multiple linear regression analysis for sap flow as a function of leaf area (LA) and reference evapotranspiration (ETo)

\begin{tabular}{lcccc}
\hline & \multicolumn{2}{c}{ African } & \multicolumn{2}{c}{ Gefner } \\
\hline & Coefficient & P-value & Coefficient & P-value \\
\hline \multicolumn{5}{c}{ Young orchard } \\
Intersept & -0.42 & 0.22 & -2.34 & $<0.01$ \\
ETo & 0.32 & $<0.01$ & 1.21 & $<0.01$ \\
LA & 0.14 & $<0.01$ & 0.24 & $<0.01$ \\
Adjusted $\mathrm{r}^{2}$ & 0.34 & 0.40 & \\
\hline \multicolumn{5}{c}{ Adult orchard } \\
Intersept & -12.32 & $<0.01$ & -5.70 & $<0.01$ \\
ETo & 5.44 & $<0.01$ & 2.83 & $<0.01$ \\
LA & 0.51 & $<0.01$ & 0.39 & $<0.01$ \\
Adjusted $\mathrm{r}^{2}$ & 0.37 & & 0.53 & \\
\hline
\end{tabular}



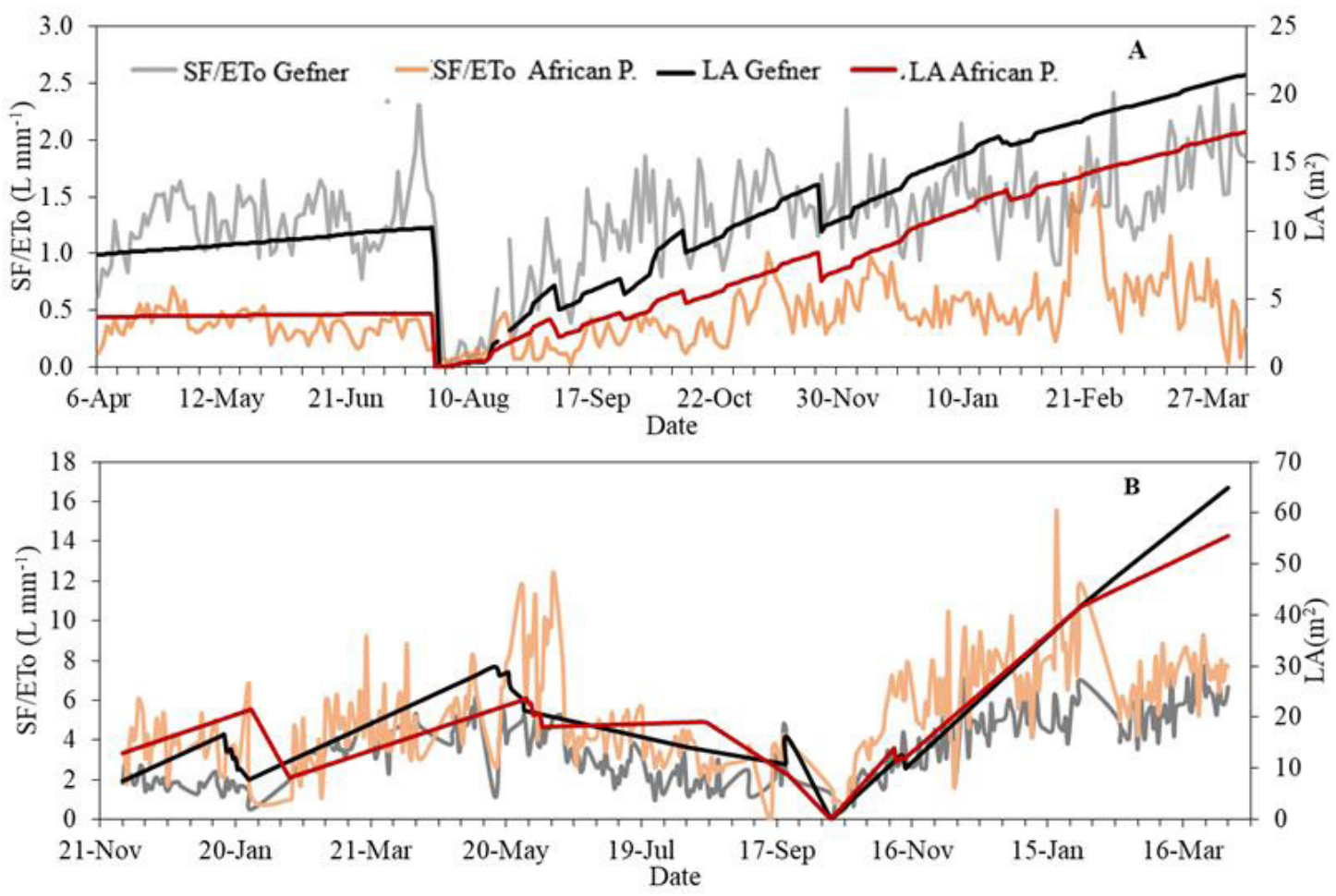

Figure 1. Leaf area course (LA) and sap flow ratio by the mean reference evapotranspiration (SF/ETo) of cultivars under study in young (a) and adult (b) atemoya orchards.

Figure $1 \mathrm{~b}$ shows the evolution of the relationship between leaf area and the mean SF/ETo ratio for plants of the adult orchard. Analyzing the first cycle, it was observed that during the first four months after January pruning, high vegetative crop vigor was observed with intense leaf area growth. However, from June to August, reduction in this growth rate was also observed. According to Taiz et al. (2017), plants can reduce their leaf area by decreasing the division and expansion of leaf cells, changing leaf shapes and initiating leaf senescence and abscission. In fact, atemoya plants, being semideciduous, reduce their cell activity, with leaf loss during autumn/winter to enter a new cycle. Bortella et al., (2020) worked with different shading conditions in Dipteryx alata seedlings and observed that variations in the number of leaves were dependent, among other factors, on the leaf senescence and abscission process, responsible for the maintenance of the photosynthetic apparatus of plants, being influenced by the physiological age of leaves or by some kind of environmental stress. During the first cycle of atemoya crop, the leaf area in adult plants reached maximum value of $37 \mathrm{~m}^{2}$ for the 'Gefner' cultivar and $36 \mathrm{~m}^{2}$ for the 'African Pride' cultivar, while, in the second cycle, this value was approximately 71.4 and $61,2 \mathrm{~m}^{2}$, respectively, for the two cultivars. The simultaneous vegetative growth events and time of formation and growth of atemoya fruits, from January to May 2018, reflected in increased sap flow. However, from June onwards, there was reduction in values, caused by the period of fruit ripening and harvesting, with subsequent leaf senescence from August onwards, reducing the sap circulation rate. The average sap flow for this period was $15.6 \mathrm{~L} \mathrm{plant}^{-1}$ day $^{-1}$ for the 'Gefner' variety and $23.8 \mathrm{~L}$ plant $^{-1}$ day $^{-1}$ for the 'African Pride' variety, reaching maximum values of 29.3 and $60.1 \mathrm{~L}$ plant ${ }^{-1}$ day $^{-1}$, respectively. The accumulated sap flow during this period was $2746.4 \mathrm{~L}$ and $4193.7 \mathrm{~L}$, with applied water volume of $6621.6 \mathrm{~L}$.

From the second vegetative growth cycle onwards, it was possible to closely monitor the relationship between leaf area and the SF/ETo ratio in both orchards. It was observed that with the occurrence of drastic pruning, sap flow values tend to zero. However, with the emission of new leaves and branches, sap flow values rapidly increase, following the plant's growth. Such behavior occurs because the sap circulation rate increases when the plant is in intense vegetative growth phase, presenting intense cell division and growth. Sap flow stabilization was observed even with continued leaf area growth. The results found revealed behavior different from that found by Oliveira et al. (2009), who estimated the maximum transpiration in mango cultivars and observed a proportional increase in transpiration with plant leaf area, regardless of plant variety and size. Thus, the generation of models to estimate transpiration through leaf area and reference evapotranspiration must be carried out carefully, as it is necessary to take into account that the plant often does not transpire linearly according to the leaf area throughout its growth period, which can lead to overestimation of the water blade applied to crops. 
It was found that the relationship between SF/ETo and leaf area lost linearity after a period, increasing only up to a certain leaf area limit. Through the use of segmented linear regression, two distinct stages were identified (Figure 2): a first stage in which the sap flow showed strong correlation with leaf area. This stage occurs when the leaf area is less than $9.24 \mathrm{~m}^{2}$ and $7.71 \mathrm{~m}^{2}$ in the young orchard, and $28.1 \mathrm{~m}^{2}$ and $31.1 \mathrm{~m}^{2}$ in the adult orchard, for the 'Gefner' and 'African Pride' varieties, respectively. When the leaf area is greater than this threshold, there was no correlation with sap flow and the lack of correlation in the second stage may be related to the fact that, despite the greater leaf growth, which would contribute to higher transpiration rate, the architecture of leaves changes, with tendency to self-shading, which causes differentiated energy absorption by leaves, reduction in stomatal conductance and, consequently, decrease in transpiration.

Based on information obtained about each cultivar and considering that sap flow can be estimated from the average leaf area and ETo, Figure 3 presents the relationships generated by these factors considering the respective leaf area limits.

The relationship between observed and estimated sap flow revealed that the model is able to explain from 52 to $41 \%$ of variations due to the variables used, with $\mathrm{RMSE}=1.41$ and $0.97 \mathrm{~L} \mathrm{day}^{-1}$ of water for 'Gefner' and 'African Pride' young plants, respectively. In the adult orchard, there is good fit of data for the 'Gefner' variety, with determination coefficient of 0.67 and $\mathrm{RMSE}=4.81$ L. For the 'African Pride' variety, only $38 \%$ of the sap flow variation can be explained by the model, presenting error of $9.59 \mathrm{~L}$.

In the young orchard, when plants had high leaf area, the average daily sap flow for the 'Gefner' cultivar was $6.10 \mathrm{~L} \mathrm{plant}^{-1}$, with maximum value of $10.2 \mathrm{~L} \mathrm{plant}^{-1}$; for the 'African Pride' cultivar, the average SF value was $2.60 \mathrm{~L} \mathrm{plant}^{-1}$, and the maximum value was $8.45 \mathrm{~L} \mathrm{plant}^{-1}$. The accumulated sap flow was 1189,2 L for the 'Gefner' cultivar and 506.4 L for the 'African Pride' cultivar, with total irrigation volume of $2343 \mathrm{~L}$ applied during the period.

In the adult orchard, when plants had high leaf area, the average sap flow was $24.3 \mathrm{~L} \mathrm{plant}^{-1}$ day $^{-1}$ for the 'Gefner' cultivar, and 36.6 L plant ${ }^{-1}$ day $^{-1}$ for the 'African Pride' cultivar, with maximum values of 50.1 and 98.2 $\mathrm{L}$ plant ${ }^{-1}$, respectively. The average accumulated sap flow was 3306,7 L for 'Gefner' cultivar and 4972,6 L for 'African Pride' cultivar, with total irrigation volume of $8328,1 \mathrm{~L}$ applied during the period. The highest SF values of plants in relation to the first cycle are associated with crop production. In the second cycle, pollination contributed to greater fruit formation, which, consequently, increased the plant's water requirement, increasing soil water extraction, especially from November to January, time of fruit formation and growth. The productivity for this period was $6.5 \mathrm{t} \mathrm{ha}^{-1}$ for the 'Gefner' variety and 6.2 t ha ${ }^{-1}$ for the 'African Pride' variety, values close to those described by Manica et al. (2003) for atemoya, obtaining from 7 to $9 \mathrm{t} \mathrm{ha}^{-1}$ per harvest.

The soil moisture variation that occurred during the experimental period may explain part of data dispersion. The soil water matric potential values for the young orchard ranged from -0.8 to $-68.6 \mathrm{kPa}$ for the 'Gefner' variety, and from -0.6 to $-73.28 \mathrm{kPa}$ for the 'African Pride' variety. In the adult orchard, during the first crop cycle, the soil water potential ranged from -0.4 to $-85.4 \mathrm{kPa}$ for the 'Gefner' cultivar and from -1.7 to $-58.1 \mathrm{kPa}$ for the 'African Pride cultivar. During the second cycle, values ranged from -1.1 to $-51.4 \mathrm{kPa}$ for the 'Gefner' cultivar and from -1.3 to $-79.1 \mathrm{kPa}$ for the 'African Pride' cultivar. Low soil water values were related to operational problems, in which water supply was not available at some moments during the experiment. However, it was found that most of the time, the matric potential values were greater than $-30 \mathrm{kPa}$.

The relationships between sap flow and canopy diameter and its interaction with the soil water content and/or associated with obtaining stomatal conductance, leaf temperature and photosynthesis measurements under different plant water conditions may encourage the conduction of further works in this area. 

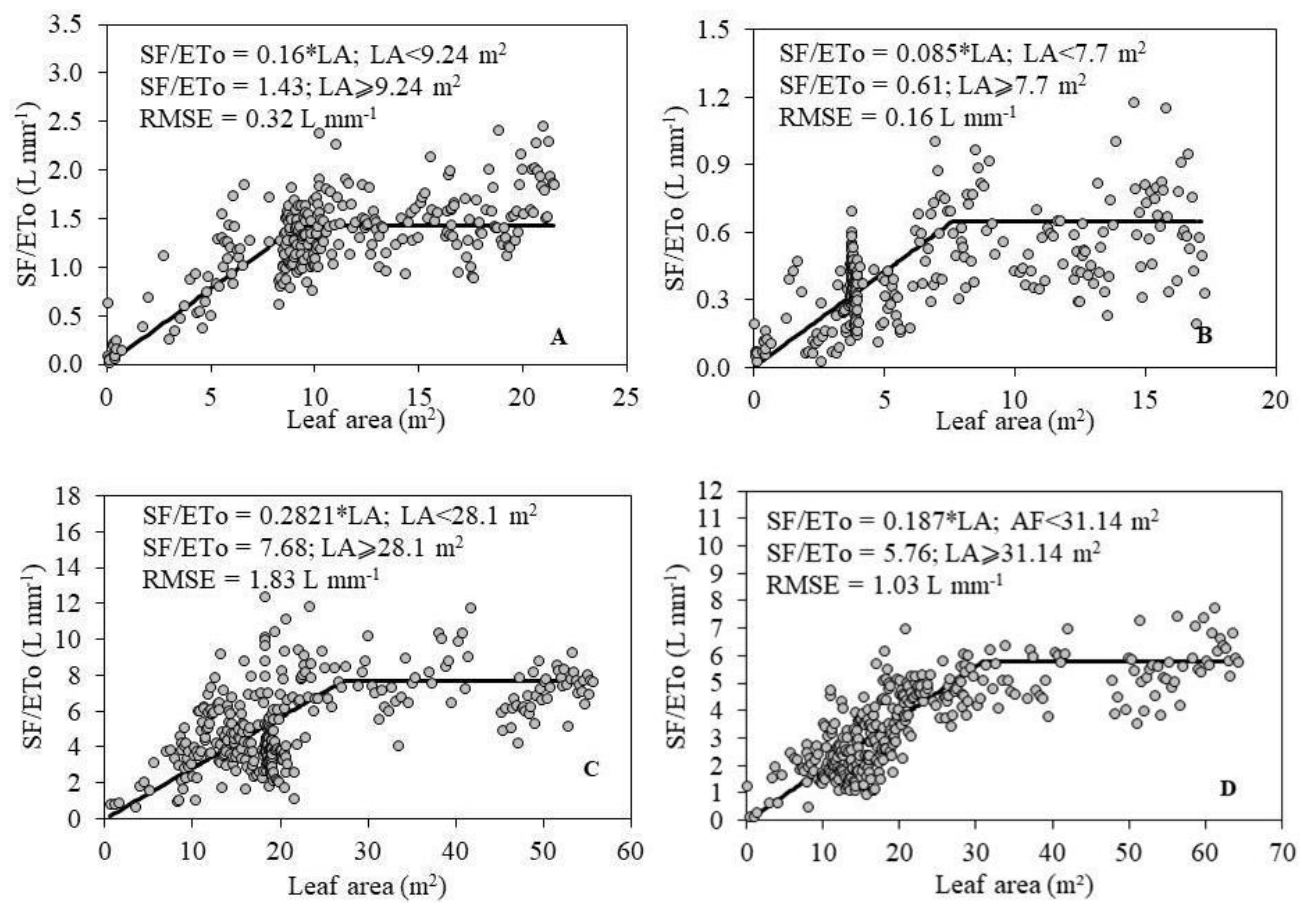

Figure 2. Relationship between sap flow and reference evapotranspiration (SF/ETo) as a function of mean leaf area (LA) of 'Gefner' (A and C) and 'African Pride' (B and D) atemoya cultivars in young (A and B) and adult (C and D) orchards.
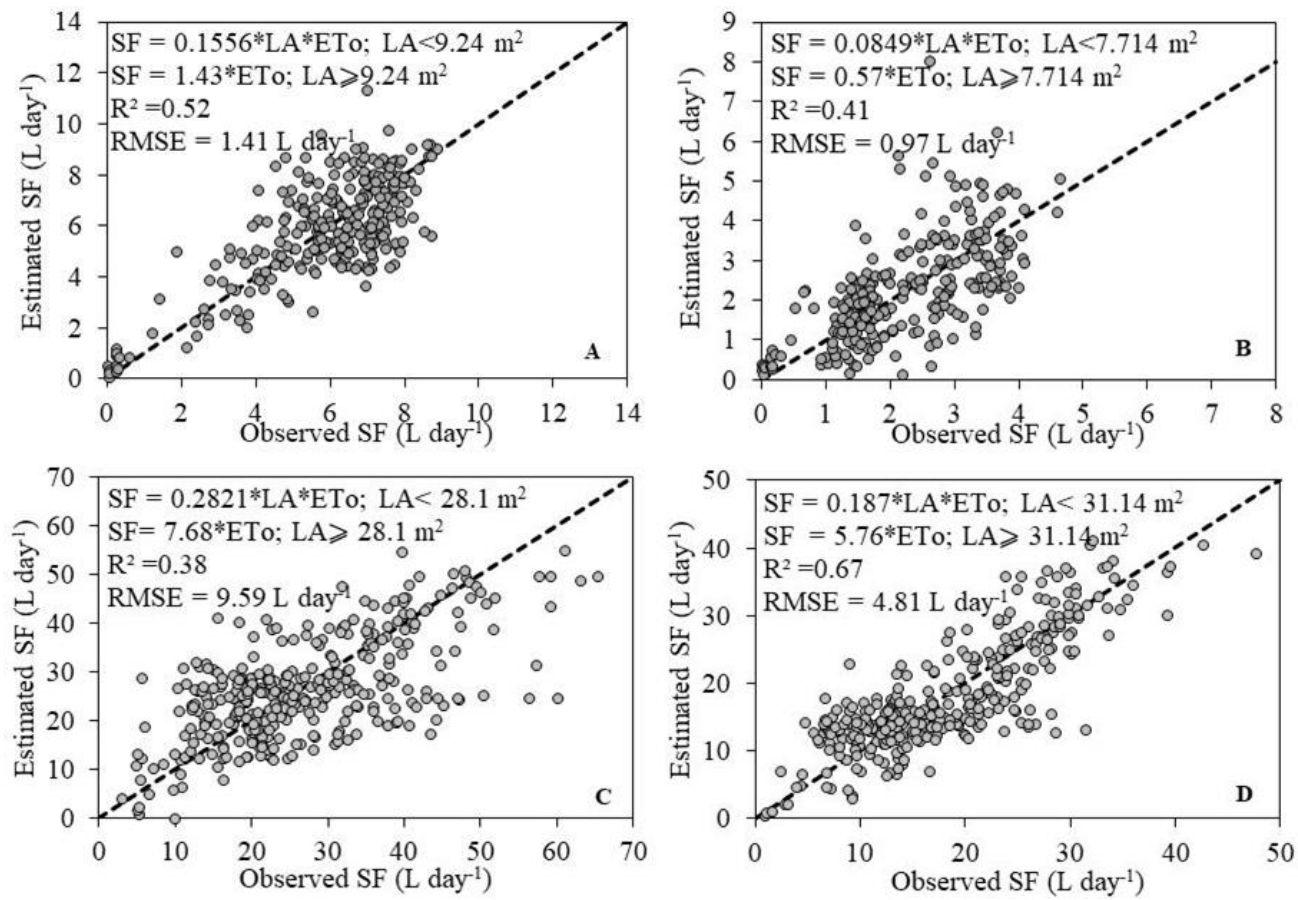

Figure 3. Relationship of sap flow (SF) observed and estimated by mean leaf area (LA) and reference evapotranspiration (ETo) in 'Gefner' (A and C) and 'African Pride' atemoya cultivars (B and D) in young (A and B) and adult (C and D) orchards. 


\section{Conclusions}

Atemoya sap flow, in the young orchard, reached maximum values of 10.2 and $8.4 \mathrm{~L} \mathrm{plant}^{-1} \mathrm{day}^{-1}$ for the 'Gefner' and 'African Pride' cultivars, respectively. In the adult orchard, these values were $50.1 \mathrm{~L} \mathrm{plant}^{-1}$ day $^{-1}$ for the 'Gefner' cultivar and 98.2 $\mathrm{L} \mathrm{plant}^{-1}$ day $^{-1}$ for the 'African Pride' cultivar.

The relationship between sap flow/reference evapotranspiration ratio and leaf area showed linear relationship up to certain LA values, indicating possible self-shading.

Sap flow estimation from the product between leaf area and reference evapotranspiration can be used in planning the irrigation of atemoya plants, provided that the leaf area limits in which this relationship occurs in each variety are considered.

\section{References}

ALLEN, R.G.; PEREIRA, L.S.; RAES, D.; SMITH, M. Crop evapotranspiration - guidelines for computing crop water requirements. Rome: FAO, 1998. 307p. (Irrigation and Drainage Paper, 56).

BORELLA, D.R.; SOUZA, A.P.; SILVA, A.C.; FELIPE, R.T.A; SILVA, K.N.C; SOUZA, J.H.G. Exigências térmicas e filocrono de Dipteryx alata sob níveis de sombreamento na transição Cerrado-Amazônia. Revista Scientia Plena, v.16, n.5, 2020. Disponível em: https://scientiaplena.emnuvens.com.br/sp/article/ view/5302/2276. Acesso em: 14 jul. 2021.

BRICKELL, C.; JOYCE, D. Pruning and training, revised new edition; over 800 plants; what, when and how to pruning. London: DK Publishing, 2017. 336p.

COELHO FILHO M.A.; ANGELOCCI, L.R.; ROJAS, J.S.D.; CAMPECHE, L.F.S.M.; FOLEGATTI, M.V. Relações entre transpiração máxima, área foliar e evapotranspiração de referência em pomar jovem de lima ácida 'Tahiti'. Revista Brasileira de Agrometeorologia, Santa Maria, v.12, n.2, p.265-274, 2004.

COELHO FILHO, M.A.C.; BASSOI, L.H.; ANGELOCCI, L.R.; COELHO, E.F..; PEREIRA, F.A.C. Relação soloplanta- atmosfera. In: SOUSA, V.F. de; MAROUELLI, W.A.; COELHO, E.F.; PINTO, J.M.; COELHO FILHO, M.A. (ed.). Irrigação e fertirrigação em fruteiras e hortaliças. Brasília, DF: Embrapa Informação Tecnológica, 2011. p.27-90.
GRANIER, A. Une nouvelle methode pour la measure du flux de seve brute dans le tronc des arbres. Annales Sciences Forestieres, Paris, v.42, p.193-200, 1985.

HAWERROTH, F.J.; MARTINS, M.V.V.; AZEVEDO, A.E.C. Uso da desfolha para indução da brotação de atemoleiras 'Gefner'. Revista Brasileira de Fruticultura, Jaboticabal, v.36, n.4, p.1041-1045. 2014.

HÖLTTÄ, T.; LINKOSALO, T.; RIIKONEN, A.; SEVANTO, S.; NIKINMAA, E. An analysis of Granier sap flow method, its sensitivity to heat storage and a new approach to improve its time dynamics. Agricultural and Forest Meteorology, Amsterdam, v.211/212, p.212. 2015.

KLARISYA L.; DANINGSIH. E. Stomatal number and size of ornamental dicotyledons plant in pontianak west kalimantan. EPiC Series in Biological Sciences, v.1, p.61-66, 2021. Disponível em: https://easychair.org/ publications/paper/ptgc. Acesso em: 14 jul. 2021.

LEMOS, E.E.P. A produção de anonáceas do Brasil. Revista Brasileira de Fruticutura, Jaboticabal, v.36, p.77-85, 2014.

MATA-GONZÁLEZ, R.; MCLENDON, T.; MARTIN, D. W. The inappropriate use of crop transpiration coefficients $\left(\mathrm{K}_{\mathrm{c}}\right)$ to Estimate evapotranspiration in arid ecosystems: a review. Arid Land Research and Management, v.19, n.3, p.285-295, 2005. Disponível em: https://www.researchgate.net/publication/254925722 The Inappropriate Use of Crop Transpiration Coefficients_Kc to Estimate Evapotranspiration in Arid_Ecosystems_A_Review. Acesso em: 17 jul . 2021.

MOSCA, J.L.; CAVALCANTE, C.E.B.; DANTAS, T.M. Características botânicas das principais anonáceas e aspectos fisiológicos de maturação. Fortaleza: Embrapa Agroindústria Tropical, 2006. 28p. (Documentos, 106).

OLIVEIRA, G.X.S.; COELHO FILHO, M.A.; PEREIRA, F.A. de C.; COELHO, E.F.; PAZ, V.P. da S.; CASTRO NETO, M.T. Relações entre transpiração máxima, evapotranspiração de referência e área foliar em quatro variedades de mangueira. Revista Brasileira de Fruticultura, Jaboticabal, v.31, p.20-27, 2009.

PAÇO, T.A.; PÔÇAS, I.; CUNHA, M.; SILVESTRE, J.C.; SANTOS, F.L.; PAREDES, P.; PEREIRA, L.S. Evapotranspiration and crop coefficients for a super intensive olive orchard. An application of SIMDualKc and METRIC models using ground and satellite observations. Journal of Hydrology, v.519, p.2067-2080, 2014. 
PEREIRA, A. B.; VILLA NOVA, N. A.; ALFARO, A. T. Necessidades hídricas de citros e macieiras a partir da área foliar e da energia solar. Revista Brasileira de Fruticultura, Jaboticabal, v.31, n.3. p. 671-679. 2009.

PETERS R.L; FONTI, P; FRANK, D.C.; POYATOS, R.; PAPPAS, C; KAHMEN, A; CARRARO, V; PRENDIN, A.L; SCHNEIDER, L.; BALTZER, J.L; BARONGAFFORD, G.A., DIETRICH, L; HEINRICH, I.; MINOR, R.L; SONNENTAG, O.; MATHENY, A.M; WIGHTMAN, M.G.; STEPPE, K. Quantification of uncertainties in conifer sap flow measured with the thermal dissipation method. New Phytologist, Oxford, v.219, p.1283-1299, 2018.

PIMENTEL, C. A relação da planta com a água. Seropédica: Edur. 2004. 191 p.

SANTOS, I.M.S.; VELLAME, L.M.; ARAÚJO, J.F.; MARINHO, L.B. Calibration of the thermal dissipation probe for atemoya (Annona squamosa $\mathrm{x}$ A. cherimola). Engenharia Agrícola, Jaboticabal, v.40, n.4, p.545-554, 2020.

SIMÕES, W.L.; COELHO, E.F.; COELHO FILHO, M.A.; GUIMARÃES, M.J.M.; SANTOS, M.R.; COSTA, E.L. Transpiration, water extraction, and root distribution of Tahiti lime (Citrus latifolia Tanaka) plant under different micro-sprinkler placements. African Journal of Agricultural Research, Ago-Iwoye v.14, n.31, p.13691378, 2019.
SILVA, T. G. F. Zoneamento agroclimático do Estado da Bahia para a cultura da atemóia (Annona cherimola Mill. x Annona squamosa L.). 2006. 104 f. Dissertação (Mestrado em Meteorologia Agrícola) - Universidade Federal de Viçosa, Viçosa, 2006.

TAIZ, L.; ZEIGER, E.; MOLLER, I.; MURPHY, A. Fisiologia e desenvolvimento vegetal. 6.ed. Porto Alegre: Artmed, 2017. 888 p.

VAN GENUCHTEN, M.T. A closed-form equation for predicting the hydraulic conductivity of unsaturated soils. Soil Science Society of American Journal, Madison, v.44, p.892- 898, 1980.

VELLAME, L.M.; COELHO FILHO, M.A.; PAZ, V.P.S. Transpiração em mangueira pelo método Granier. Revista Brasileira de Engenharia Agrícola e Ambiental, Campina Grande, v.13, n.5, p.516-523, 2009.

VELLAME, L.M; COELHO FILHO, M.A.; PAZ, V. P. S; COELHO, E.F. Gradientes térmicos naturais na estimativa do fluxo de seiva pelo método Granier. Revista Caatinga, Mossoró, v.24, n.1, p.116-122. 2011.

WIGHT, J.R.; HANSON, C.L.; COOLEY, K.R. Modeling evapotranspiration from sagebrush-grass rangeland. Journal of Range Management, Baltimore, v.39, p.81-85, 1986. 